\title{
Recent observations supporting the hypothesis of the colonization of thrombolite plattorms by mangroves
}

\section{Observaciones recientes que apoyan la hipótesis sobre la colonización de plataforrmas tromboliticas por mangles}

\author{
David Alfaro Siqueiros Beltrones ${ }^{1}$, Janette Magally Murillo Jiménez² and Rubén Esteban García Gómez ${ }^{3}$
}

${ }^{1}$ Instituto Politécnico Nacional. Departamento de Plancton y Ecología Marina. Centro Interdisciplinario de Ciencias Marinas (CICIMAR) Av. Instituto Politécnico Nacional S/N, Col. Playa Palo de Santa Rita, La Paz, BCS. 23096. México 2Instituto Politécnico Nacional. Departamento de Oceanología. CICIMAR ${ }^{3}$ Instituto Politécnico Nacional. Departamento de Servicios Educativos. CICIMAR e-mail: dsiquei@gmail.com

Recibido: 23 de febrero de 2016. Aceptado: 19 de octubre de 2016

Siqueiros Beltrones, D. A., J. M. Murillo Jiménez and R. E. García Gómez. 2017. Recent observations supporting the hypothesis of the colonization of thrombolite platforms by mangroves. Hidrobiológica 27(1): 119-121. D0l: 10.24275/uam/izt/dcbs/hidro/2017v27n1/SiqueirosB

\begin{abstract}
Background. Thrombolites are sedimentary structures formed by precipitation, consolidation, and lithification of sediments generated by the evolution of cyanophyte mats that are responsible for coastal ground formation. Mangroves, however, are opportunist that colonize said substratum, in this case thrombolite platforms. Goals. To provide recent evidence of mangrove colonization of thrombolite platforms. Methods. Photographic images were taken of specimens of mangroves found fixed on the first thrombolite platform described in 2005. The platform was examined and samples were collected to analyze their mineralogical composition. Results. Evidence was gathered of two mangrove species colonizing a thrombolite platform. Specimens that had reached significant heights, indicating healthy juveniles, were found fixed on the first thrombolite platform. Collected platform structures were identified as rhizoliths belonging to mangrove trees. Conclusions. Evidence is presented that, besides this colonizing event, an earlier colonization on a thrombolite platform occurred at an inferior level. A secondary hypothesis that micrite would be a significant component of the rhizolith structure was proven through the mineralogical analysis of rhizolith fragments.
\end{abstract}

Key words: Colonization, mangroves recruits, micrite, microbial mats, pro-thrombolites.

\section{RESUMEN}

Antecedentes. Los trombolitos son estructuras sedimentarias formadas por precipitación, consolidación y litificación de sedimentos debido a la actividad y crecimiento de tapetes de cianofitas y son considerados responsables de la formación de suelo costero; mientras que los mangles son oportunistas que colonizan las plataformas trombolíticas. Objetivos. Proporcionar evidencias de que ocurre colonización de plataformas trombolíticas por mangles. Métodos. Se tomaron imágenes fotográficas de especímenes de mangle presentes en la primera plataforma trombolítica descrita en 2005. Se examinó la plataforma y se tomaron muestras para analizar su composición mineralógica. Resultados. Se reunieron evidencias de colonización de una plataforma trombolítica por mangles. Los especímenes observados sobre la plataforma trombolítica son juveniles saludables con alturas notables. Las muestras de plataforma resultaron estructuras sedimentarias conocidas como rizolitos de raíces de mangle. Conclusiones. Se presentan evidencias de que, además de este evento de colonización, existió una colonización anterior en una plataforma localizada en un estrato inferior. Mediante el análisis mineralógico se probó la hipótesis de que la micrita sería un componente significativo de la estructura de los rizolitos.

Palabras clave: Colonización, reclutas de mangle, micrita, protrombolitos, tapetes microbianos.

This short report was generated by a casual observation of the first pro- thrombolite platform discovered in 2005 in La Paz lagoon (Baja California Sur, Mexico) that was later described together with similar formations (Siqueiros Beltrones, 2008), although not before fully lithified structures or thrombolites in this area were recorded (Siqueiros Beltrones et al., 2006). Thrombolites are sedimentary structures formed by precipitation, consolidation, and lithification of sediments generated by evolution of cyanophyte mats into pro-thrombolites and eventually 
thrombolites. A seven-year study went idle after the publication of the proposed theory about the origin of thrombolite and pro-thrombolite formations and their ecological and geomorphological consequences (Siqueiros Beltrones et al., 2012). Unlike the serendipity behind the whole theory of pro-thrombolite processes, this report is supported by the above theory and includes the required testing of a derived hypothesis, i.e., mangroves are actually opportunistic plants that take advantage of the available substrate (Siqueiros Beltrones et al., 2012), with effective recruiting occurring in any of the following three stages: mat formation mainly by filamentous cyanophytes; development of prothrombolites; conformation of thrombolite platforms (Figs 1a-b). In the originally described pro-thrombolite platform, no mangrove plants were observed (Figs 1c-d). The first published images from which said platform was discovered showed only marsh vegetation such as Salicornia sp. (Siqueiros Beltrones, 2008). Ten years have gone by so that any mangrove recruits show evidence of having established themselves on the platform. Although abundant germlings have been observed in the area afixed on cyanophyte mats, many of them turned out to be ephemeral (Siqueiros Beltrones et al., 2012); in fact, only some of those observed on thrombolite platforms may eventually develop into fully grown mangrove trees. Here we provide photographic evidence that depict healthy juveniles of two species of mangrove: two specimens of Avicennia germinans (L.) Stearn, and one of Laguncularia racemosa (L.) C.F. Gaertn (Fig. 1e) that have reached significant heights on the originally described pro-thrombolite platform. Likewise, another L. racemosa recruit, about the same size, had grown on the second thrombolite platform observed around $200 \mathrm{~m}$ away, close to an A. germinans adult (Fig. 1b); the young specimens reached heights of between 120 $\mathrm{cm}$ and $160 \mathrm{~cm}$.

Examination of the (first) platform fragmented by erosion revealed structures identified as rhizoliths belonging to mangrove trees (Fig. 1f), similar to those recorded earlier from across the La Paz lagoon in the EI Mogote sandbar (Siqueiros Beltrones, 2008). We considered the former to be evidence that an earlier colonization on a thrombolite platform occurred at an inferior level. Said levels have been documented earlier eastward at Calerita (Baja California Sur), east of El Mogote, a nonlacunar environment were no mangroves are found but alleged evidences of their earlier presence was discussed (Siqueiros Beltrones et al., 2012). In order to gather more sound evidence on the process involved in the evolution of this platform, mineralogical analysis of rhizolith fragments was conducted to test the hypothesis that micrite would be a significant component of the rhizolith structure, proposed earlier as the main cementing agent in thrombolite formation (Siqueiros Beltrones, 2008; Siqueiros Beltrones et al., 2012). To identify the micrite, vertical and horizontal thin sections of two rhizolith fragments were prepared and analyzed under a petrographic microscope. Because of their poor consolidation, they had to be fixed with epoxy resin. The cross section revealed no alignment or any other type of arrangement, as in Johnson et al. (1999). Their form and composition, however, suggested an ichnofossil derived from plant roots, i.e., of a rhizolith. We concluded that both samples were initially the same type of muddy sand-rock with a calcareous matrix; the mud component consisting of micrite (aragonite), was most likely produced by disintegration or erosion of bivalve shells or calcareous algae. These observations support our earlier hypothesis. Moreover, the mineralogical analysis showed diagenic characteristics such as neomorphism in the aragonite and calcite, which allows us to place the samples at the beginning of a deep diagenic range, although, due to a differential degree of diagenesis the amount of substituted matrix varied between the samples. In addition, the presence of aragonitic oolites corresponds with a shallow lacunar or estuarine environment, where thrombolite processes and mangroves are common.

Previously, it was acepted that mangroves functioned as sediment traps that eventually cause ground formation (Dawes, 1981; Kathiresam, 2003). According to our previous studies (Siqueiros Beltrones, 2008; Siqueiros Beltrones et al., 2012), ground formation is initially carried out by cyanobacterial mats through binding, stabilizing, and clotting of sediments, leading to the development of pro-thrombolite platforms, and that these substrates are opportunistically colonized by mangrove recruits; it is thus a preexisting process that is accelerated by mangroves after colonizing suitable areas (Woodroffe, 1992) such as those provided by pro-thrombolite and thrombolite platforms. Our observations provide further evidence that thrombolite and pro-thrombolite platforms are, along with thick cyanophyte mats, the substrates most likely to promote colonization by mangroves (Siqueiros Beltrones et al., 2012), evolving from an organic mat, and passing through the stages of conglomerate mats and pro- thrombolite platforms, into sedimentary rock by micrite deposition (Siqueiros Beltrones, 2008; Siqueiros Beltrones et al., 2012). The characteristic calcareous matrix and micritic (aragonite) mud of the analyzed rhizolith samples suggests a similar process that generates thrombolite platforms in a shallow lacunar environment. Micrite may be considered an adequate element to trace the early formation of thrombolites inland. For example, it could be useful to confirm the mangrove origin of other rhizoliths, such as those recorded by Johnson et al. (1999) that showed an internal concentric structure, while ours did not and were identified by external form and site association as described by these authors. Because much of the ground formation has to be attributed to growth of non-consolidated pro-thrombolites with much less cementing micrite (Siqueiros Beltrones et al., 2012), we are impelled to seek still another element relating the three stages of thrombolite evolution in coastal ground formation.

\section{ACKNOWLEDGEMENTS}

Rhizolith samples were processed by L. J. Cota. DASB is COFAA and EDI fellow of the Instituto Politécnico Nacional.

\section{REFERENCES}

Dawes, C. J. 1981. Marine Botany. John Wiley \& Sons Ltd. 628 p. DOI: $10.1017 /$ S0025315400019913

Johnson, M. E., J. Ledesma-Vázouez, M. A. Mayall \& J. Minch. 1997. Upper Pliocene stratigraphy and depositional systems: The Peninsula Concepción basins in Baja California Sur, México. In: Johnson, M.E. \& J. Ledesma-Vázquez (Eds.). Pliocene carbonates and related facies flanking the Gulf of California, Baja California, México. Special paper 318, Geological Society of America. pp. 57-72.

KatHIRESAM, K. 2003. How do mangrove forests induce sedimentation? Revista de Biología Tropical 51 (2): 355-360.

Siqueiros Beltrones, D. A. 2006. Diatomeas bentónicas asociadas a trombolitos recientes en la Ensenada de La Paz, B.C.S., México. CICIMAR-Oceánides 21 (1-2): 113-143. 

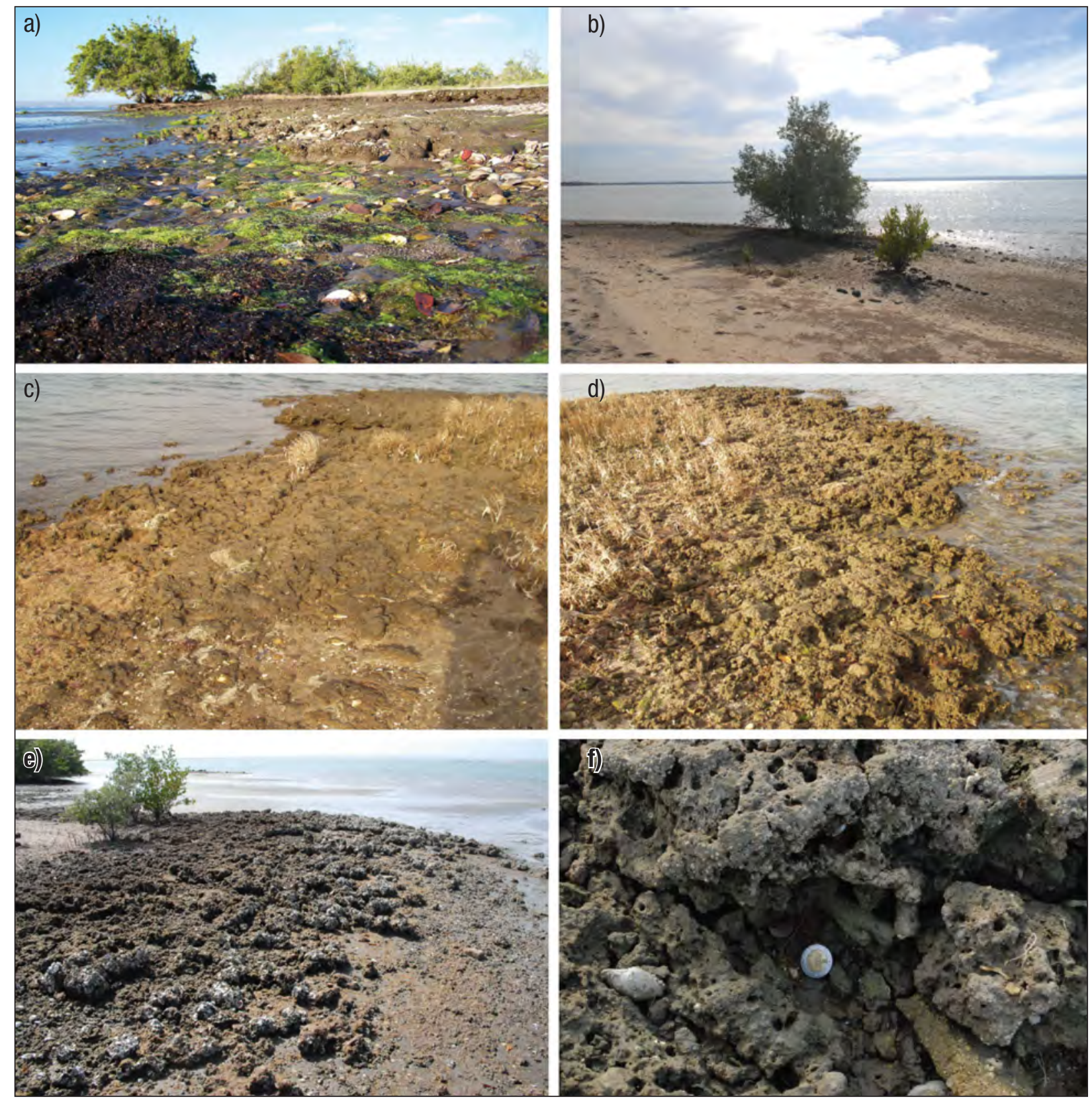

Figures 1a-f. a) Adult specimen of Avicennia germinans living on thrombolithic substrate next to an extended pro-thrombolite platform at El Mogote, La Paz lagoon. b) Adult A. germinans and recently settled juvenile of $L$. racemosa West. c), d) East views of the first described thrombolite platform in 2005 where settlement of mangrove trees has ocurred ten years after. e) East view of platform showing short mangrove trees in 2015. f) Rhizoliths found beneath the thrombolite platform.

Siqueiros Beltrones, D. A., U. Argumedo Hernández \& 0.U. Hernández AlmelDA. 2006. Trombolitos litificados dentro de la Ensenada de La Paz, B.C.S., México. CICIMAR Oceánides 21 (1, 2): 155-158.

Siquelros Beltrones, D. A. 2008. Role of pro-thrombolithic processes in the geomorphology of a coastal lagoon. Pacific Science 62 (2): 257269. DOI: 10.2984/1534-6188(2008)62[257:ROPITG]2.0.C0;2

Siqueiros Beltrones, D. A., 0. U. Hernández Almeida \& J. Murillo Jiménez. 2012. Pro-thrombolites and the origin of coastal lagoons in
Northwestern México. Hidrobiológica 22 (3): 244-257.

Siqueiros-Beltrones, D. A., E. F. Félix-Pico \& 0. U. Hernández Almeida. 2009. Stratigraphic evidence of pro-thrombolithic ground formation around the La Paz lagoon (México). CICIMAR-Oceánides 24 (1): 59-63.

Woodroffe, C. 1992. Mangrove sediments and geomorphology. In: Robertson, A.I. \& D.M. Alongi (Eds.). Tropical mangrove ecosystem. American Geophysical Union. Washington DC. pp. 7-41. DOI: 10.1029/CE041 